\title{
Chromosomal Localization of the Genes for the Vitronectin and Fibronectin Receptors $\alpha$ Subunits and for Platelet Glycoproteins IIb and IIIa
}

\author{
Donna M. Sosnoski," Beverly S. Emanuel, "\$ Anita L. Hawkins, ” Peter van Tuinen," David H. Ledbetter," \\ Robert L. Nussbaum,"*s Fa-Ten Kaos,' Elias Schwartz," David Phillips, * * \\ Joel S. Bennett, "\# Laurence A. Fitzgerald, ** and Mortimer Poncz ${ }^{*}$ \\ *Howard Hughes Medical Institute, University of Pennsylvania School of Medicine, Philadelphia, Pennsylvania 19104; ${ }^{\ddagger}$ Department of \\ Pediatrics, ${ }^{\S}$ Human Genetics and ${ }^{\ddagger}$ Medicine, University of Pennsylvania School of Medicine Philadelphia, Pennsylvania 19104; \\ "Institute for Molecular Genetics, Baylor College of Medicine, Houston, Texas 77009; 'Eleanore Roosevelt Institute for Cancer \\ Research, Denver, Colorado 80201; and **Gladstone Foundation Laboratories for Cardiovascular Disease, University of California, \\ San Francisco, California 94117
}

\begin{abstract}
The integrins, a family of related membrane receptors involved in cell-cell and cell-matrix interactions, are heterodimeric complexes of $\alpha$ and $\beta$ subunits. To begin to understand the evolution of these complexes, we studied the genomic organization of several $\alpha$ and $\beta$ integrin subunits. Using both somatic cell hybrids and an in situ hybridization technique, we have determined the chromosomal location of the genes for the $\alpha$ subunits of the vitronectin receptor $\left(\mathrm{VNR}_{\alpha}\right)$, the fibronectin receptor (FNR $_{\alpha}$, and for the $\alpha$ subunit of the platelet glycoprotein IIb/IIIa complex, GPIIb. In addition, we have determined the chromosomal location of the gene for the $\beta$ subunit of the GPIIb/IIIa heterodimer, GPIIIa. Our studies indicate that the $\alpha$ subunits do not localize to a single locus, but that each is found on a different chromosome. The gene for $\mathrm{VNR}_{\alpha}$ is located on chromosome 2, the gene for $\mathrm{FNR}_{\alpha}$ is on chromosome $12 q 11 \Rightarrow 13$, and the gene for GPIIb is on chromosome $17 q 21 \Rightarrow 23$. In contrast to the chromosomal dispersion of the $\alpha$ subunits, the genes for GPIIb and GPIIIa are physically close, with the gene for GPIIIa also located on chromosome $17 q 21 \Rightarrow 23$. These studies indicate that the genes for the $\alpha$ subunits of the integrin family have been dispersed during evolution while GPIIb and GPIIIa are in close physical proximity. This physical proximity of GPIIb and GPIIla may be involved in the concurrent expression of these proteins by megakaryocytes, and may result in linkage disequilibrium between these two genes, which would limit the use of restriction length polymorphisms in linkage studies of GPIIb/IIIa abnormalities in small kindreds.
\end{abstract}

\section{Introduction}

The integrins are a family of heterodimeric protein complexes involved in cell-cell and cell-matrix interactions. Integrins

Address all correspondence to Dr. Mortimer Poncz, The Children's Hospital of Philadelphia, 34th Street and Civic Center Boulevard, Philadelphia, PA 19104.

Received for publication 16 November 1987 and in revised form 21 March 1988.

J. Clin. Invest.

(c) The American Society for Clinical Investigation, Inc.

0021-9738/88/06/1993/06 $\$ 2.00$

Volume 81, June 1988, 1993-1998 function in tissue migration during embryogenesis, cellular adhesion, thrombosis, and lymphocyte helper and killer cell functions (1). Included in this family are the platelet glycoprotein IIb/IIIa (GPIIb/IIIa) ${ }^{1}$ complex (2), the LFA-1/Mac-1/ p150,95 complexes found on myeloid and lymphoid cells ( 3 , 4 ), and the fibronectin and vitronectin receptors found on many different cell types (5-7).

Previous immunologic and biochemical studies indicate that the integrins are composed of a larger $\alpha$ subunit and a smaller $\beta$ subunit (1). Recently, cDNA for several different $\alpha$ and $\beta$ subunits have been cloned (8-15). Analysis of the amino acid sequences deduced from these clones indicates a significant similarity among the various $\alpha$ subunits and among the various $\beta$ subunits. Thus, there is $36-45 \%$ amino acid identity between the $\alpha$ subunits of human fibronectin receptor (FNR), vitronectin receptor (VNR), and GPIIb (14), and $42-47 \%$ amino acid identity between the $\beta$ subunits of chick integrin, human LFA-1/Mac-1/p150,95, and GPIIIa (8, 11, $13,15)$.

We have begun a study of the genomic organization of the $\alpha$ and $\beta$ subunits of several integrins to better understand the evolution and function of these receptors. We report here the chromosomal localization of the genes for the $\alpha$ subunits of FNR and VNR and for GPIIb. In addition, we have determined the location of the gene for GPIIIa.

\section{Methods}

Preparation of DNA. Probes used in this study include a near fulllength 3.2-kb GPIIb cDNA in the M13mp18 phage (12), a 2.3-kb cDNA fragment representing the $5^{\prime}$ end of GPIIIa in the M13mp18 phage (15), a 2.3-kb fragment representing the $3^{\prime}$ end of the FNR cDNA in the M13mp18 phage (14), and a 2.8-kb VNR $\mathrm{VNDNA}_{\alpha}$ in the plasmid PUC13 (14).

Phage and plasmid DNAs were prepared by alkaline denaturation and were purified using a cesium chloride gradient $(16,17)$. GPIIb,

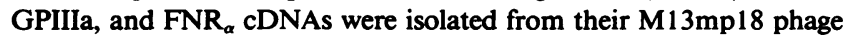
using Eco RI digestion, while a 1.6-kb subfragment of the 2.8-kb VNR was obtained by digestion with Hind III. The digested DNAs were size-fractionated on $0.7 \%$ agarose gels, and the cDNA insert bands were electroeluted (International Biotechnologies, Inc.).

Somatic cell hybrid studies. High molecular weight DNA was prepared, following published procedures (18), from a Chinese hamster

1. Abbreviations used in this paper: FNR, fibronectin receptor; GP, glycoprotein; VNR, vitronectin receptor. 
lung cell line (RJK88), a normal human lymphoblastoid line (VTL217), a mouse fibroblast line (M613), and from somatic cell hybrids of human/hamster and human/mouse origin. For each hybrid used in these studies, cytogenetic analysis by trypsin G-banding was performed simultaneously with DNA preparation (19). The retained human chromosomes of some of these cell hybrids have been defined previously (20-24). The human chromosomal composition of the three new hamster-human somatic cell lines, MR7.11, MR6.13, and MR8.21, is as shown in Table I. The human chromosomal composition of cell line MGL66-1 differed from that published previously and is also shown in Table $I$.

Southern blot analyses were performed as previously described (25). Briefly, $12 \mu \mathrm{g}$ of genomic DNA was digested with $5 \mathrm{U} / \mu \mathrm{g}$ of an appropriate restriction endonuclease, electrophoresed in $0.8 \%$ agarose gels in TAE buffer ( $40 \mathrm{mM}$ Tris acetate, $\mathrm{pH} \mathrm{7.4,1} \mathrm{mM} \mathrm{EDTA)} \mathrm{for} 26 \mathrm{~h}$ at $30 \mathrm{~V}$, and transferred to Zetabind membrane filters. Filters were prehybridized and hybridized in accordance with published procedures (26). The four CDNA probes were ${ }^{32} \mathrm{P}$-labeled by random primer extension (27) to $>10^{8} \mathrm{cpm} / \mu \mathrm{g}$ of DNA.

Chromosomal assignment for each of the four cDNAs was made by Southern blot analysis of a panel of somatic cell hybrids. The restriction enzymes used to digest the DNA for these blots were those that produced readily distinguishable human-specific restriction fragments. Assignments were based on the known retained human chromosomes in each somatic cell hybrid and on the human-specific restriction fragment pattern generated by each probe. The term "discordance" used in these studies refers to the percent of somatic cell hybrid lines whose results do not agree with the assignment of a gene to that chromosome.

Table I. Summary of Somatic Cell Hybrid Analysis Using GPIIb, GPIIIa, FNR ${ }_{\alpha}$ and VNR Probes $_{\alpha}$

\begin{tabular}{|c|c|c|c|c|c|c|c|c|c|c|c|c|c|c|c|c|c|c|c|c|c|c|c|c|c|c|c|}
\hline \multicolumn{28}{|c|}{ Initial screen } \\
\hline Cell line & 竞 & 总 & $\frac{\alpha^{*}}{z^{\prime}}$ & $\frac{\alpha}{z}$ & 1 & 2 & 3 & 4 & 5 & 6 & 7 & 8 & 9 & 10 & 11 & 12 & 13 & 14 & 15 & 16 & 17 & 18 & 19 & 20 & 21 & 22 & $\mathbf{x}$ \\
\hline MR7.11 & $\mathbf{N}$ & $\mathbf{N}$ & $\mathbf{Y}$ & $\mathbf{N}$ & - & - & - & - & - & - & - & - & + & - & + & - & + & - & - & - & - & - & - & + & - & + & + \\
\hline 8.2 & $\mathbf{N}$ & $\mathbf{N}$ & $\mathbf{Y}$ & $\mathbf{Y}$ & - & + & + & + & - & - & + & + & - & + & + & + & - & + & + & + & - & - & - & + & - & - & + \\
\hline MR4.11 & $\mathbf{Y}$ & $\mathbf{Y}$ & $\mathbf{Y}$ & $\mathbf{N}$ & - & - & + & - & - & + & + & - & - & + & + & - & + & - & - & - & - & - & - & + & - & + & + \\
\hline C.A. & $Y$ & $\mathbf{Y}$ & $\mathbf{Y}$ & $\mathbf{N}$ & - & - & + & + & + & + & - & - & - & - & + & + & - & + & + & + & + & + & - & - & + & + & + \\
\hline MR5.11 & $\mathbf{N}$ & $\mathbf{N}$ & $\mathbf{N}$ & $\mathbf{Y}$ & + & + & + & - & - & - & + & - & + & + & + & - & + & - & - & + & - & + & - & - & + & + & + \\
\hline MR6.13 & $\mathbf{N}$ & $\mathbf{N}$ & $\mathbf{Y}$ & $\mathbf{Y}$ & - & + & - & - & - & - & + & - & - & - & + & - & + & + & + & - & - & - & - & - & - & - & + \\
\hline 13.1 & $\mathbf{N}$ & $\mathbf{N}$ & $\mathrm{N}$ & $\mathbf{N}$ & - & - & + & - & - & + & - & - & - & - & + & - & - & - & - & + & - & - & - & + & - & + & + \\
\hline 2.13 & $\mathrm{~N}$ & $\mathbf{N}$ & $\mathbf{N}$ & $\mathbf{N}$ & + & - & - & - & - & - & - & - & - & - & + & - & - & + & - & - & - & + & - & - & + & - & + \\
\hline 1.15 & $\mathrm{~N}$ & $\mathbf{N}$ & $\mathbf{N}$ & $\mathbf{N}$ & - & - & - & - & - & + & - & + & - & - & + & - & - & - & - & - & - & + & - & - & - & - & + \\
\hline \multirow[t]{5}{*}{ MR8.21 } & $\mathbf{N}$ & $\mathbf{N}$ & $\mathbf{N}$ & $\mathbf{N}$ & + & - & - & - & - & - & - & - & - & - & - & - & - & - & - & - & - & - & - & - & - & - & + \\
\hline & & & \multicolumn{2}{|c|}{ GPIIb } & 50 & 60 & 30 & 20 & 10 & 20 & 40 & 40 & 40 & 30 & 70 & 20 & 50 & 40 & 30 & 40 & 10 & 40 & 20 & 40 & 30 & 30 & 80 \\
\hline & & & \multicolumn{2}{|c|}{ GPIIIa } & 50 & 60 & 30 & 20 & 10 & 20 & 40 & 40 & 40 & 30 & 70 & 20 & 50 & 40 & 30 & 40 & 10 & 40 & 20 & 40 & 30 & 30 & 80 \\
\hline & & & \multicolumn{2}{|c|}{$\mathrm{FNR}_{\alpha}$} & 80 & 60 & 40 & 30 & 40 & 50 & 30 & 50 & 50 & 40 & 40 & 30 & 30 & 30 & 20 & 50 & 40 & 70 & 50 & 40 & 60 & 40 & 50 \\
\hline & & & \multicolumn{2}{|c|}{$\mathrm{VNR}_{\alpha}$} & 40 & 0 & 40 & 30 & 40 & 70 & 10 & 30 & 30 & 20 & 60 & 30 & 20 & 30 & 20 & 30 & 40 & 40 & 30 & 50 & 40 & 60 & 70 \\
\hline
\end{tabular}

GPIIb, GPIIIa \& VNR $\alpha$ secondary screen

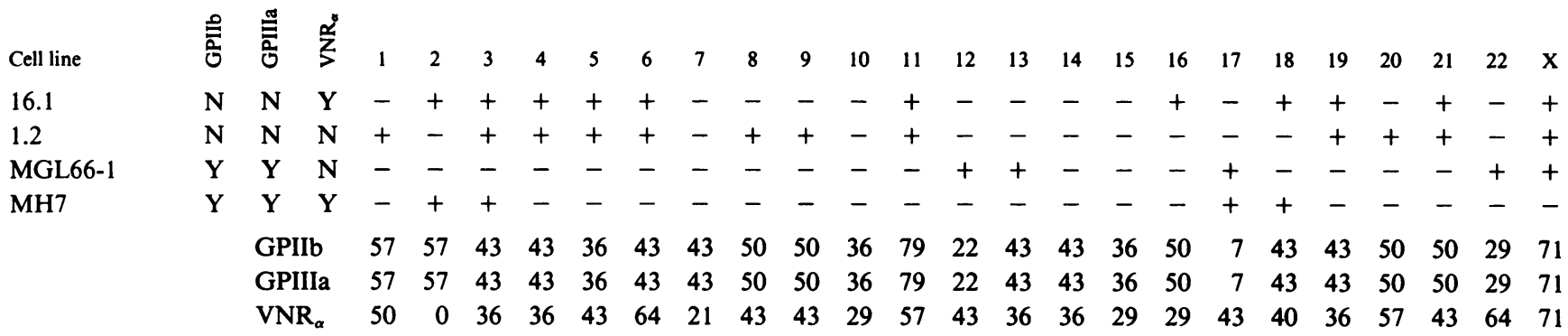

FNR $\alpha$ secondary screen

\begin{tabular}{|c|c|c|c|c|c|c|c|c|c|c|c|c|c|c|c|c|c|c|c|c|c|c|c|}
\hline Cell line & 压 & 1 & 2 & 3 & 4 & 5 & 6 & 7 & 8 & 9 & 10 & 11 & 12 & 13 & 14 & 15 & 16 & 17 & 18 & 19 & 20 & 21 & 22 \\
\hline 1.4 & $\mathbf{N}$ & - & - & + & + & - & - & - & - & - & - & - & - & - & - & - & + & - & - & + & - & + & - \\
\hline MGL2 & $\mathbf{N}$ & - & - & - & + & - & + & - & - & + & - & - & - & - & - & - & - & - & - & - & - & + & + \\
\hline $12 a$ & $\mathbf{Y}$ & - & - & - & - & - & - & - & - & - & - & - & + & - & - & - & - & - & - & - & - & - & - \\
\hline CP3-1 & $\mathbf{Y}$ & - & - & - & + & + & - & - & - & - & - & + & + & - & + & - & + & + & + & + & + & + & - \\
\hline CP18-1 & $\mathbf{N}$ & + & - & - & - & - & - & - & + & - & - & + & - & - & + & + & - & + & + & + & - & - & - \\
\hline & & 73 & 53 & 47 & 40 & 33 & 66 & 33 & 53 & 53 & 40 & 40 & 20 & 33 & 33 & 33 & 47 & 47 & 60 & 53 & 33 & 60 & 47 \\
\hline
\end{tabular}

Results for each probe are indicated to the left of the line. A "Y" refers to detection of a human band on Southern blot analysis, while a "N" refers to the absence of a human band. To the right of the line, the known human chromosomes found within each somatic cell hybrid line are indicated. "+" Refers to the presence of that chromosome in the cell line and "-" refers to its absence. Under each table, discordance is shown (as a percent) for each probe studied. 
In situ hybridization studies. In situ hybridizations were performed using FNR ${ }_{\alpha}$, GPIIb, and GPIIIa cDNAs in the purified phages. For these studies, the cDNAs were ${ }^{3} \mathrm{H}$-labeled by nick translation to a specific activity of $1-2 \times 10^{7} / \mu \mathrm{g}(28)$. Metaphase chromosomes were prepared from PBLs of two normal males. In situ hybridization was performed as previously described (29). Slides were developed after 14-25 $\mathrm{d}$ and banded using a modified Wright Giemsa method (30). Grain distribution over the chromosomes was then determined. Duplicate studies were performed for each gene studied.

\section{Results}

Somatic cell hybrids. Genomic DNA from a Chinese hamster cell line and from a normal human lymphoblastoid cell line was digested with each of several restriction endonucleases, sized on agarose gels, blotted, and probed with cDNA probes for GPIIb, GPIIIa, VNR $\alpha$, and FNR ${ }_{\alpha}$ to determine which restriction endonucleases best distinguished human DNA bands from hamster-related bands (data not shown). For GPIIb, GPIIIa, and FNR ${ }_{\alpha}$, Eco RI digestion most readily distinguished between the species, while Bgl II gave the clearest result for $\mathrm{VNR}_{\alpha}$. Southern blots were then performed using a panel of 10 human/hamster hybrids $(20,24)$ (Table I). Based on these results, additional hybrid cell lines containing more restricted selections of human chromosomes were used to determine the chromosomal location of each gene.

$G P I I b / G P I I I a$. When hybridized against the initial screening panel, the cDNA for GPIIb and GPIIIa gave identical results and had a minimal discordance of $10 \%$ for both chromosomes 5 and 17 (Table I). To resolve this ambiguity, hybridizations were performed with two human/hamster hybrids that contained chromosome 5 but not chromosome 17 (cell lines 16.1 and 1.2) (20) and with two cell lines, a human/hamster hybrid (MGL66-1) and a human/mouse hybrid (MH-7 [ 22]), that contained chromosome 17 but not chromosome 5. These studies indicated that both GPIIb and GPIIIa were located on chromosome 17 with an overall discordance of $7 \%$.

To localize the genes for GPIIb and GPIIIa further, Southern blots were performed using a panel of mouse/human and hamster/human hybrid cell lines containing partial segments of chromosome 17 (Fig. 1) (31). These blots revealed that the genes for both GPIIb and GPIIIa are present on the long arm of chromosome 17 between $\mathrm{q} 21 \Rightarrow 23$.

$V N R_{\alpha}$. The initial and secondary somatic cell hybrid panels used to study GPIIb and GPIIIa were also used to localize the $\mathrm{VNR}_{\alpha}$ gene as shown in Table I. This gene appears to map to chromosome 2 as this chromosome had $0 \%$ discordance in the 14 cell lines studied, and no other chromosome was discordant for less than 3 of the 14 cell lines.

$F N R_{\alpha}$. Analysis of the initial hybridization using the so-

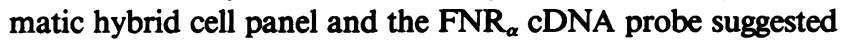
several possible chromosome locations for the FNR $_{\alpha}$ gene (Table I). In particular, chromosome 15 gave a discordance of $20 \%$. However, none of the chromosomes had a very high concordant frequency, indicating that this initial panel was not adequate for assigning the location of the FNR $\alpha$ gene. A second panel was assembled using five other human/hamster cell hybrids from various sources including 1.4 (20), MGL66-2 (21), 12a (23), CP3-1 (23), and CP18-1 (23). The results of these hybridizations clearly placed $\mathrm{FNR}_{\alpha}$ on chromosome 12, as shown by its overall $20 \%$ discordance and by the positive

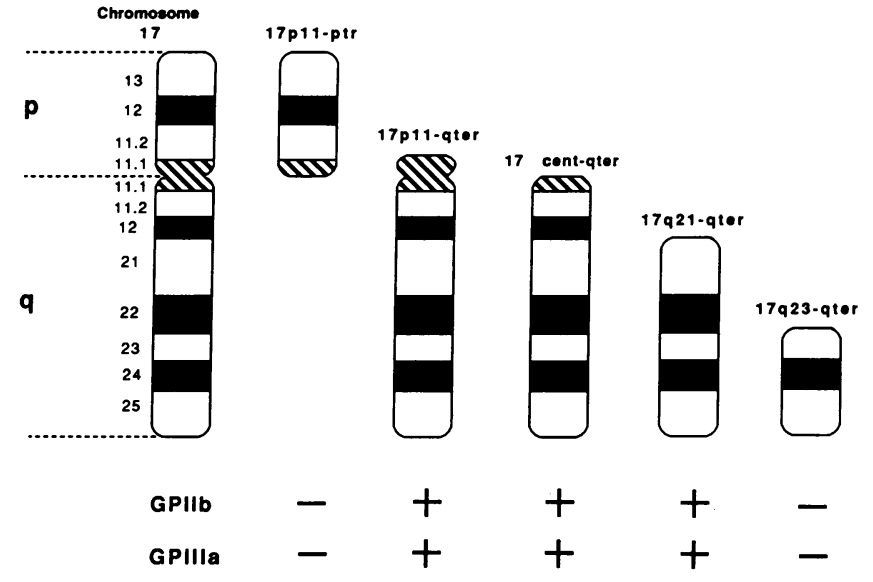

Figure 1. Somatic cell hybrid localization of GPIIb and GPIIIa to $17 \mathrm{q} 21 \Rightarrow 23$. A diagrammatic representation of chromosome 17 is shown on the left and the subfragments contained within the various somatic cell lines tested are shown to the right. The results of hybridization to GPIIb and GPIIla are shown underneath. "+", A detectable human band on Southern blot analysis with that cell line; and "-", the absence of a detectable human band.

results with hybrid $12 \mathrm{a}$, which contains only human chromosome 12.

In situ hybridization studies. To confirm the chromosomal

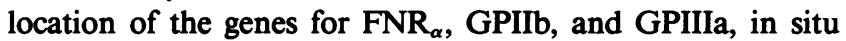
hybridizations were performed using metaphase chromosomes from human lymphocytes and CDNA probes for $\mathrm{FNR}_{\alpha}$, GPIIb, and GPIII. To localize the $\mathrm{FNR}_{\alpha}$ gene, 142 grains on 75 metaphases were analyzed (Fig. 2). The predominant site of hybridization was the proximal long arm of chromosome 12 , with a total of 19 grains $(16 \%)$ at bands $12 q 11 \Rightarrow 13$. These findings support the chromosomal assignment based on the somatic cell hybrid studies described above, and sublocalizes the $\mathrm{FNR}_{\alpha}$ gene to $12 \mathrm{q} 11 \Rightarrow 13$.

To localize the GPIIb gene, 132 grains were counted over 75 metaphases and a total of 17 grains $(13 \%)$ were over the predominant site of hybridization at bands $17 \mathrm{q} 21 \Rightarrow 22$ (Fig. 2 ). To localize the GPIIIa gene, 227 grains were counted over 75 metaphases (Fig. 2). Of these, $37(16 \%)$ of the total were present at the predominant site of hybridization $17 q 21 \Rightarrow 23$. These experiments indicate that the genes for GPIIb and GPIIIa are on the proximal long arm of chromosome 17.

\section{Discussion}

We have determined the chromosomal location of the genes for three different integrin $\alpha$ subunits. We found that the genes for $\mathrm{FNR}_{\alpha}, \mathrm{VNR}_{\alpha}$, and GPIIb are located on chromosomes $12 \mathrm{q} 11 \Rightarrow 13,2$, and $17 \mathrm{q} 21 \Rightarrow 23$, respectively. While this work was in progress, Bray et al., using dual laser chromosome sorting, has also localized GPIIb to chromosome 17 (32). Previously, Marlin et al., in studies of somatic hybrid cell lines using antibodies against the $\alpha$ subunit of the human lymphocyte LFA- 1 complex, found that the gene for this $\alpha$ subunit is located on chromosome 16 (33). Thus, while analysis of the cDNA sequences for these integrin $\alpha$ subunits indicates that they are structurally similar and suggests that they may have evolved from a common ancestral form, the genes do not occupy a single locus, but are dispersed on different chromo- 

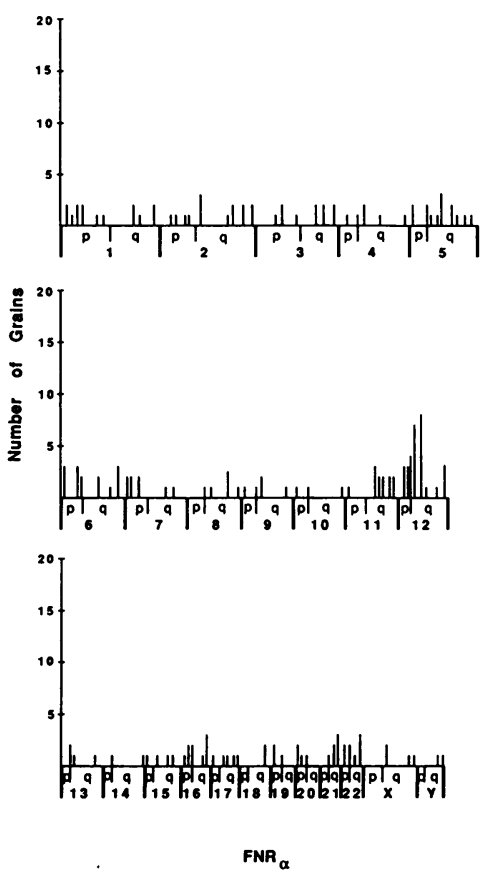
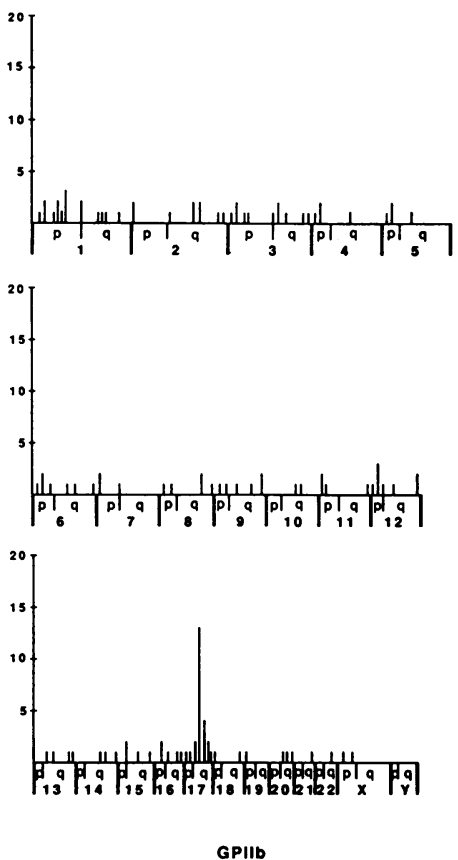
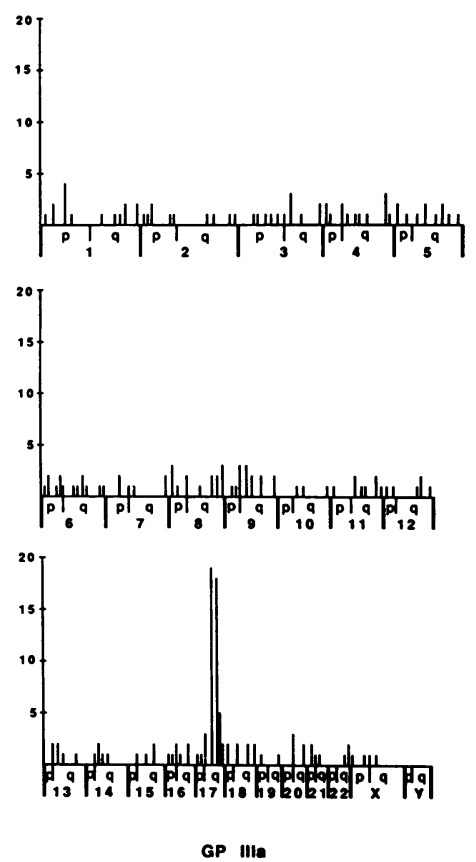

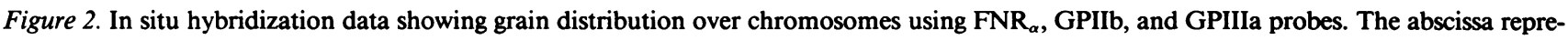
sents the chromosomes in their relative size proportions and the ordinate shows the number of silver grains.

somes. Likewise the genes for the integrin $\beta$ subunits are distributed on different chromosomes. Using cDNA for GPIIIa, we found that the gene for this protein is located on chromosome $17 q 21 \Rightarrow 23$, which is consistent with a recent abstract reporting the localization of GPIIIa to chromosome 17 by dual laser chromosome sorting (34). Previous analysis of somatic hybrid cell lines, using complement and antibody studies, indicated that the genes for the $\beta$ subunits of LFA- 1 and VLA-1 are located on chromosomes 21 and 10 , respectively $(35,36)$. Integrin-like complexes have also been demonstrated in Drosophila. These complexes, termed the position-specific antigens, are thought to be involved in cell adhesion during morphogenesis (35). The presence of integrin and integrin-like receptors in insects, birds (37), and mammals suggests that these cell adhesion complexes arose early in evolution, and may account for the wide chromosomal dispersion of the genes for these homologous proteins.

GPIIb and GPIIIa are concurrently expressed by early megakaryocytes (38). In platelets, these proteins form a calcium-dependent surface membrane heterodimer that functions as a receptor for fibrinogen, fibronectin, vitronectin, and von Willebrand factor after platelet activation (39-41). We found that the genes for the $\alpha$ and $\beta$ subunits of the platelet GPIIb/IIIa complex localize to the proximal portion of the long arm of chromosome 17 at $\mathrm{q} 21 \Rightarrow 23$ and that somatic cell hybrids that contain fragments of chromosome 17 indicate that the genes for GPIIb and GPIIIa cosegregate (Table I and Fig. 1). In the autosomal recessive disorder, Glanzmann thrombasthenia, GPIIb/IIIa receptor function is defective, and in the platelets of many thrombasthenic patients, the quantity of platelet GPIIb and GPIIIa are decreased to a similar extent (42). This suggests that in the latter cases, the expression of GPIIb and GPIIIa may be concurrently regulated. It is tempting to speculate that the physical proximity of the genes for GPIIb and GPIIIa may be involved in the parallel decrease of these proteins. However, in endothelial cells, the gene for GPIIIa is expressed concurrently with the gene for $\mathrm{VNR}_{\alpha}$, which is located on chromosome $2(14,15,43)$. Moreover, normal synthesis of a GPIIIa-containing complex has been observed in umbilical vein endothelial cells of a thrombasthenic newborn (44). Thus, the genetic basis for the concurrent expression of GPIIb and GPIIIa in megakaryocytes, and for the parallel deficiency of both proteins seen in many thrombasthenic individuals, is likely to be more complicated than the simple physical proximity of the GPIIb and GPIIIa genes might suggest.

While the basis for the GPIIb/IIIa abnormalities in thrombasthenia is unknown, in an analogous disorder, the leukocyte adhesion deficiency syndrome, deficient expression of the LFA-1/Mac-1/p150/95 heterodimers appears in several cases to be due to an abnormality of the common 95,000 mol wt $\beta$ subunit (45). Similarly, with the availability of cDNA probes for GPIIb and GPIIIa, it may be possible to determine which of the GPIIb/IIIa genes is affected in thrombasthenics from a particular kindred. The physical proximity demonstrated in this paper for GPIIb and GPIIIa may result in linkage disequilibrium between these genes, which may interfere with the use of restriction fragment length polymorphisms in such family studies when assigning the defect to either GPIIb or GPIIIa.

\section{Acknowledgments}

This work was supported by grants from the National Institutes of Health (HL-37419, HL-28947, HL-32254, CA-39926, GM-32592, CA-09485, AM-16691, HD-02080, HD-20619, HD-06814, and HL-23809), The Council for Tobacco Research-U.S.A., Inc. (1570), the University of Pennsylvania, and the March of Dimes. 


\section{References}

1. Hynes, R. O. 1987. Integrins: a family of cell surface receptors. Cell. 48:549-554.

2. Jennings, L., and D. Phillips. 1982. Purification of glycoproteins IIb and III from human platelet plasma membranes and characterization of a calcium-dependent glycoprotein IIb-III complex. J. Biol. Chem. 257:10458-10463.

3. Springer, T. A. 1985. The LFA-1, Mac-1 glycoprotein family and its deficiency in an inherited disease. Fed. Proc. 44:2660-2663.

4. Anderson, D. C., and T. A. Springer. 1987. Leukocyte adhesion deficiency: an inherited defect in the Mac-1, LFA-1, and p150,95 glycoproteins. Annu. Rev. Med. 38:175-194.

5. Giancotti, F. G., G. Tarone, K. Knudsen, C. Damsky, and P. M. Comoglio. 1985. Cleavage of a $135 \mathrm{KD}$ cell glycoprotein correlates with loss of fibroblast adhesion to fibronectin. Exp. Cell Res. 156:182-190.

6. Pytela, R., M. D. Pierschbacher, E. Ruoslahti, G. A. Marguerie, and M. H. Ginsberg. 1985. Identification and isolation of a $140 \mathrm{kd}$ cell surface glycoprotein with properties expected of a fibronectin receptor. Cell. 45:191-198.

7. Pytela, R., M. D. Pierschbacher, and E. Ruoslahti. A 125/115$\mathrm{kDa}$ cell surface receptor specific for vitronectin interacts with the arginine-glycine-aspartic acid adhesion sequence derived from fibronectin. Proc. Natl. Acad. Sci. USA. 82:5766-5770.

8. Tamkun, J. W., D. W. DeSimone, D. Fonda, R. S. Patel, C. Buck, A. F. Horwitz, and R. O. Hynes. 1986. Structure of integrin, a glycoprotein involved in the transmembrane linkage between fibronectin and actin. Cell. 46:271-282.

9. Argraves, W. S., R. Pytela, S. Suzuki, J. L. Milan, M. D. Pierschbacher, and E. Ruoslahti. 1986. cDNA sequences from the $\alpha$ subunit of the fibronectin receptor predict a transmembrane domain and a short cytoplasmic peptide. J. Biol. Chem. 261:12922-12924.

10. Suzuki, S., W. S. Argraves, R. Pytela, H. Arai, T. Krusius, M. D. Pierschbacher, and E. Ruoslahti. 1986. cDNA and amino acid sequences of the cell adhesion protein receptor recognizing vitronectin reveal a transmembrane domain and homologies with other adhesion protein receptors. Proc. Natl. Acad. Sci. USA. 83:8614-8618.

11. Fitzgerald, L. A., B. Steiner, S. C. Rall, S. Lo, and D. R. Phillips. 1987. Protein sequence of endothelial glycoprotein IIIa derived from a cDNA clone. Identity with platelet glycoprotein IIIa and similarity to "Integrin." J. Biol. Chem. 262:3936-3939.

12. Poncz, M., R. Eisman, R. Heidenreich, S. M. Silver, G. Vilaire, S. Surrey, E. Schwartz, and J. S. Bennett. 1987. Structure of the platelet membrane glycoprotein IIb. Homology to the $\alpha$ subunits of the vitronectin and fibronectin membrane receptors. J. Biol. Chem. 262:8476-8482.

13. Kishimoto, T. K., K. O'Connor, A. Lee, T. M. Roberts, and T. A. Springer. 1987. Cloning of the $\beta$ subunit of the leukocyte adhesion protein: homology to an extracellular matrix receptor defines a novel supergene family. Cell. 48:681-690.

14. Fitzgerald, L. A., M. Poncz, B. Steiner, S. C. Rall, J. S. Bennett, and D. R. Phillips. 1987. Comparison of cDNA-derived protein sequences of the human fibronectin and vitronectin receptor $\alpha$ subunits and platelet glycoprotein IIb. Biochemistry. 26:8158-8165.

15. Butler-Zimrin, A., R. Eisman, G. Vilaire, E. Schwartz, J. S. Bennett, and M. Poncz. 1988. The structure of platelet glycoprotein IIIa. A common subunit for two different membrane receptors. J. Clin. Invest. 81:1470-1475.

16. Birnboim, H. C., and J. Doly. 1979. A rapid alkaline extraction procedure for screening recombinant plasmid DNA. Nucleic Acids Res. 7:1513-1523.

17. Poncz, M., D. Solowiejczyk, M. Ballantine, E. Schwartz, and S. Surrey. 1982. "Nonrandom" DNA sequence analysis in bacteriophage M13 by the dideoxy chain-termination method. Proc. Natl. Acad. Sci. USA. 79:4298-4302.
18. Nussbaum, R. L., W. E. Crowder, and W. L. Nyhan. 1983. A three-allele restriction-fragment-length polymorphism at the hypoxanthine phosphoribosyl transferase locus in man. Proc. Natl. Acad. Sci. USA. 80:4035-4039.

19. Seabright, M. 1971. A rapid banding technique for human chromosomes. Lancet. ii:971-972.

20. Patel, P. I., R. L. Nussbaum, P. E. Framson, D. H. Ledbetter, C. T. Caskey, and A. C. Chinault. 1984. Organization of the HPRT gene and related sequences in the human genome. Somatic Cell Mol. Genet. 10:483-493.

21. Ledbetter, D. H., S. A. Ledbetter, and R. L. Nussbaum. 1986. Implications of fragile $X$ expression in normal males for the nature of the mutation. Nature (Lond.). 324:161-163.

22. Chan, L., P. van Tuinen, D. H. Ledbetter, S. P. Daiger, A. M. Gotto, and S. H. Chen. 1985. The human apolipoprotein $\beta-100$ gene: a high polymorphic gene that maps to the short arm of chromosome 2. Biochem. Biophys. Res. Commun. 133:248-255.

23. Law, M. L., G.-Y. Cai, F.-K. Lin, Q. Wai, S.-Z. Huang, J. H. Hartz, H. Morse, C.-H. Lin, C. Jones, and F.-T. Kao. 1986. Chromosomal assignment of the human erythropoietin gene and its DNA polymorphism. Proc. Natl. Acad. Sci. USA. 83:6920-6924.

24. Nussbaum, R. A., R. M. Walmsley, J. G. Lesko, S. D. Airhart, and D. H. Ledbetter. 1985. Thymidylate synthetase deficient Chinese hamster cells: a selection system for the study of Ts regulation and fragile X expression. Am. J. Hum. Genet. 37:1192-1205.

25. Southern, E. M. 1975. Detection of specific sequences among DNA fragments separated by gel electrophoresis. J. Mol. Biol. 98:503-517.

26. Maniatis, T., E. F. Fritsch, and J. Sambrook. 1982. Molecular Cloning: A Laboratory Manual. Cold Spring Harbor Laboratory, Cold Spring Harbor, New York. 387-389.

27. Feinberg, A. P., and B. Vogelstein. 1983. A technique for radiolabeling DNA restriction endonuclease fragments to high specific activity. Anal. Biochem. 132:6-13.

28. Maniatis, T., E. F. Fritsch, and J. Sambrook. 1982. Molecular Cloning: A Laboratory Manual. Cold Spring Harbor Laboratory, Cold Spring Harbor, New York. 109-112.

29. Harper, M. E., and G. F. Saunders. 1981. Localization of single copy DNA sequences on G-banded human chromosomes by in situ hybridization. Chromosoma (Berl.). 83:431-439.

30. Cannizzaro, L. A., and B. S. Emanuel. 1984. An improved method for G-banding chromosomes after in situ hybridization. Cytogenet. Cell Genet. 38:308-309.

31. van Tuinen, P., K. R. Johnson, S. A. Ledbetter, R. L. Nussbaum, G. Rovera, and D. H. Ledbetter. 1987. Localization of myeloperoxidase to the long arm of human chromosome 17: relationship to the $15 ; 17$ translocation of acute promyelocytic leukemia. Oncogene. 1:319-322.

32. Bray, P. F., J.-P. Rosa, G. I. Johnston, D. T. Shiu, R. G. Cook, C. Lau, Y. W. Kan, R. P. McEver, and M. A. Shuman. 1987. Platelet glycoprotein IIb. Chromosomal localization and tissue expression. $J$. Clin. Invest. 80:1812-1817.

33. Marlin, S. D., C. C. Morton, D. C. Anderson, and T. A. Springer. 1986. LFA-1 immunodeficiency disease: definition of the genetic defect and chromosomal mapping of the $\alpha$ and $\beta$ subunits of the lymphocyte function-associated antigen 1 (LFA-1) by complementation in hybrid cells. J. Exp. Med. 164:855-867.

34. Rosa, J.-P., P. F. Bray, O. Gayet, G. I. Johnston, R. G. Cook, M. A. Shuman, and R. P. McEver. 1987. Cloning of glycoprotein IIIa cDNA from human erythroleukemia (HEL) cells: sequence polymorphism and colocalization of the glycoprotein IIb and glycoprotein IIIa genes to chromosome 17. Blood. 70:359a. (Abstr.)

35. Peters, M. S., M. E. Kamarck, M. E. Hemler, J. L. Strominger, and F. H. Ruddle. 1984. Genetic and biochemical characterization of human lymphocyte cell surface antigens: the A-1A5 and A-3A4 determinants. J. Exp. Med. 159:1441-1454.

36. Brower, D. L., M. Wilcox, M. Piovant, R. J. Smith, and A. R. 
Lorrel. 1984. Related cell-surface antigens expressed with positional specificity in Drosophila imiginal discs. Proc. Natl. Acad. Sci. USA 81:7485-7489.

37. Tamkun, J. W., D. W. DeSimone, D. Fonda, R. S. Patel, C. Buck, A. F. Horwitz, and R. O. Hynes. 1986. Structure of Integrin, a glycoprotein involved in the transmembrane linkage between fibronectin and actin. Cell. 46:271-282.

38. Rabellino, E. M., R. B. Levine, L. L. K. Leung, and R. L. Nachman. 1981. Human megakaryocytes II. Expression of platelet proteins in early marrow megakaryocytes. J. Exp. Med. 154:88-100.

39. Bennett, J. S., J. A. Hoxie, S. F. Leitman, G. Vilaire, and D. B. Ceines. 1983. Inhibition of fibrinogen binding to stimulated platelets by a monoclonal antibody. Proc. Natl. Acad. Sci. USA. 80:2417-2421.

40. Pytela, R., M. D. Pierschbacher, M. H. Ginsberg, E. F. Plow, and E. Ruoslahti. 1986. Platelet membrane glycoprotein IIb/IIIa: member of a family of arg-gly-asp-specific adhesion receptor. Science (Wash. DC). 231:1559-1562.

41. Plow, E. F., R. P. McEver, B. S. Coller, V. L. Woods, G. A.
Marguerie, and M. H. Ginsberg. 1985. Related binding mechanisms for fibrinogen, fibronectin, von Willebrand factor, and thrombospondin on thrombin-stimulated human platelets. Blood. 66:724-727.

42. Nurden, A. T., and J. P. Caen. 1979. The different glycoprotein abnormalities in thrombasthenic and Bernard Soulier platelets. Semin. Hematol. 16:234-250.

43. Ginsberg, M. H., J. Loftus, J. Ryckwaert, M. Pierschbacher, R. Pytela, E. Ruoslahti, and E. F. Plow. 1987. Immunochemical and amino-terminal sequence comparison of two cytoadhesins indicates they contain similar or identical $\beta$ subunits and distinct $\alpha$ subunits. $J$. Biol. Chem. 262:7819-7824.

44. Giltay, J. C., O. C. Leeksma, C. Breederveld, and J. A. van Mourik. 1987. Normal synthesis and expression of endothelial IIb/IIIa in Glanzmann's thrombasthenia. Blood. 69:809-812.

45. Kishimoto, T. K., N. Hollander, T. M. Roberts, D. C. Anderson, and T. A. Springer. 1987. Heterogeneous mutations in the $\beta$ subunit to the LFA-1, Mac-1 and p150/85 glycoproteins cause leucocyte adhesion deficiency. Cell. 50:193-202. 